\title{
Rosas, the Storyless, and Roles
}

\author{
Rachel Haidu(iD) \\ Department of Art and Art History, University of Rochester, Rochester, NY 14627, USA; \\ rachel.haidu@rochester.edu
}

Received: 15 November 2019; Accepted: 22 March 2020; Published: 28 March 2020

\begin{abstract}
Analyzing the early work of Anne Teresa De Keersmaeker-and particularly Rosas danst Rosas (1983) - this article examines the notion of "the storyless" in relation to the role: that pillar of dance, and especially choreography, which enables the individuation, transmission, and exchange of each dancer's part. Set in relation to the principles of serial music that De Keersmaeker had already explored in Fase (1982) and to the idea of seriality itself, the role provides a way to consider how "storylessness" could be both emancipatory and feminist. It responds to identitarian models of feminist argumentation by suggesting that a virtue of certain forms of abstraction lies in the pleasurable ways that dance's roles demonstrate the circulability and exchangeability of the self.
\end{abstract}

Keywords: abstraction; dance; choreography; roles; serialism; postmodern; feminism; European; contemporary; stories

Storylessness, after all, has been women's big problem.

(Pollitt [1988] 2008)

Music ... is very real to me, very concrete, though 'storyless'. But storyless is not abstract. Two dancers on the stage are enough material for a story; for me, they are already a story in themselves.

(Balanchine [1966] 1992)

With these two epigraphs, I want to open up a question about the feminist value of the storyless. In particular, I am curious about whether it can be introduced as a framework within which dancers, in an emphatically multiple sense, might contribute to a feminist revaluation of the storyless. For Balanchine, any number of dancers that is greater than one introduces a sense of a story. In this case, both that sense of multiplicity and its implication of being storied run up against the feminist idea that the "big problem [of] storylessness" is a politicized problem, even a gendered one. But let us first back up and ask: Why does one dancer alone not suffice to imply "material for a story"? What are the conditions by which we distinguish between what one dancer on the stage does, and more than one? And: can dancers ever recapture the storylessness that music brings, even when their bodies might suffice to make "a story in themselves"? If so, is it possible for the potential politics of storylessness to resurface, but positively? Or at least: might we find a way that the gendering and politics of storylessness do not merely consign more bodies to a negative valuation of the storyless?

It is in her 2008 foreword to Carolyn Heilbrun's famous Writing a Woman's Life (1988) that Pollitt makes her contention about the storyless. She is introducing Heilbrun's book about women poets born in the decade between 1923 and 1933, a book that went on to major readership with a relatively simple argument at its core: "Only in the last third of the twentieth century have women broken through to a realization of the narratives that have been controlling their lives" (Heilbrun [1988] 2008, p. 60). Narratives here are huge, overarching conventions: the marriage plot is the key narrative Heilbrun has in mind. It is perhaps not surprising that one of the best-known texts articulating the question 
of "female bodies on stage", Sally Banes' (1998) Dancing Women, also centers the question of the marriage plot, analyzing even Balanchine's Agon within the framework of "women's community and the marriage plot" (p. 209). However, if narratives are conventions scaled to the massiveness of the social, the stories of Heilbrun's subjects' lives are in another category: particular, specific, belonging to each poet she writes about. One of her book's arguments is that women start writing "their own lives", creating their own stories, once they break out of these controlling narratives. Thus, the narrative, like "women", is already a category of the general, whereas the notion of "their own lives" and indeed "their stories" is a particularizing, individual, even proprietary form.

One could argue, as did Lincoln Kirstein in 1984, that Agon's complex articulation of "dancers manipulated as irreplaceable spare parts" suggests quite a different idea than what Banes articulates about the dancers' roles in Agon. Must the "stories" initiated by their bodies-assuming Balanchine is right-lead towards the domestic and purportedly permanent entanglement of the marriage plot, as she suggests (Kirstein 1984, p. 242, cited in Banes 1998, p. 208)? Let's sidestep what feels like a somewhat outdated question and focus instead on that slippage introduced by the "role", the nexus at which I wish to pick up what both Balanchine and Pollitt index, decades apart, as "storylessness". Let's ask instead: Can the dancer's role itself allow storylessness be more than a gap in conventional narratives or their antitheses in particular, heroic narratives of resistance and difference? Could storylessness, rethought through the problematic of the role, have its own expansiveness, its own qualities, even something that we could contrast with the proprietary relations of "one's own story"?

Storylessness, as a problem belonging to "women", demands that we determine how, like stories themselves, it can belong to one person at a time or many: what are its terms? In other words, "women's storylessness" might be able to work to not capture its subjects within a familiar binary, that between a conventional narrative ("all married women ...") and its antithesis (which becomes, by default, also conventional). Or, for that matter, an impossible universalism and the particularizing form in which every self gets to have her own story. The concept of storylessness might be used instead to undermine the reductiveness of the claim to have one's own story, and to discuss what that undermining might entail in an art form. Specifically, here I would like to think about the proprietary nature of "stories" in relation to a larger perspective on property relations: one in which we look not at the substance of a story (e.g., the story that itself gets told and maybe retold) as that which gets transposed or transmitted, but at the very act of transmission. Then transmission, exchange, and circulation refer us back to the ways that bodies imply stories, without necessarily filling in what those stories are. When one person - particularly, one woman - then another enters a chain of storylessness, we might see the chain itself as what is produced as a condition of selfhood. That which is subsumed and generated in the exchange is also that which belongs to-or rather creates-the one and her conditions for entering the multiple.

The name for what I am talking about is the role: that component of dance in which a part of a dance gets passed from dancer to dancer. If there are four dancers on a stage, each dances a separate role, even if one role is made up of the same moves as another. The simple fact of their spatial dispersal (or perhaps their temporal organization, so that one dancer moves on one beat, and the other on the next) means that the dance differs across the four dancers. They have each learned their own part, which includes musical and silent cues as well as spatial coordinates. The dance will also look different on each of them, thanks to the particularizing nature of bodies and how they interact with space (the angle at which I see this one, and then that one, then that one ... ). That is how dance lends particularity to that which could seem formally identical: there is no way to see this body dancing a movement as identical to that body dancing the same movement. This has as much to do with the body, the face, even the "style" or other irrevocably particularizing aspects of a dancer's performance, as it has to do with the viewer, her position vis-à-vis the dancer, her interest in or identification with that one, there, as opposed to another. (And who is to say that those interests and identifications remain consistent?) 
Dance invites not only desire but projection to play across the dancer's performance-especially when the dancer uses expression, phrasing, etc. to solicit and receive the audience's gaze. ${ }^{1}$ That standing invitation fed Yvonne Rainer's early, explicit, and paradigmatic effort to "eliminate" characterhood and its vestiges from contemporary dance (Rainer 1974, pp. 63-69). In the Grand Union's collaborative, improvisatory ethos, the kind of choreographic structure that allows the passing down of planned movements to others was intentionally avoided (let alone the ways that roles allow dance to organize in the space and time of performance; let alone the taint of story or characterhood that can so easily hitch to roles). ${ }^{2}$ However, this exclusion did not really fit Rainer's trajectory. Describing one of her last works before she stopped choreographing, Inner Appearances (1972), which was performed to a slide sequence, Rainer writes that she "hoped [that] words, isolated from a social or character-driven context, and coexisting with a task-involved figure, would in and of themselves cause a quickening in those who read them in the dark" (Rainer 2006, p. 408). That "quickening" — the spectator's sense of recognition-is key to the way I am describing roles and how they can sometimes rely on the conventionality that we quickly associate to stories. The "character-driven context" of film, faintly suggested by the pseudo-narrative slide sequence of Inner Appearances, argues against the role's abstractness, its mere vehicularity as I will be describing it. What I will emphasize is how roles can also perform the abstraction of dance-that vehicularity that enables different dancers, performing different parts of a dance, to show us that dance as a form does not rely on the particularities of this body or that one, the story this one implies or does not. That is how roles can help convey a story but also enable its other; they, like bodies themselves, can index both storylessness and the taint of story. ${ }^{3}$

Anne Teresa De Keersmaeker, the choreographer whose early work Rosas danst Rosas I discuss here, was deeply affected by a year she spent in New York City in 1981 learning about postmodern dance from choreographers such as Lucinda Childs, Trisha Brown, and Rainer. I am particularly interested in the manner in which De Keersmaeker's dance, like Rainer's early films, allows abstracting roles to converge with dance's particularizing effects. It is this convergence-the taint of personhood contaminating the role as vehicle, as mode of transmission-that makes dance such a potent form of abstract art. Dance does not need to insist on the absence of story, especially after more than a century of explicitly non-narrative dance. ${ }^{4}$ Dance always requires bodies, and bodies along with their movements bring into performance an inevitable sense of story that might just be another name for that insoluble aspect through which another's body appears to the viewer. ${ }^{5}$ (One might, in other words, question Balanchine's notion that it even takes two dancers to introduce a sense of story: as Rainer's Three Seascapes (1963) makes parodically self-evident, one dancer's body is enough to imply

1 In her memoir, Rainer describes her paradigmatic work Trio A, whose dancers keep their faces "constantly averted from the spectator's gaze" so as to keep those faces "unreadable with regard to expression, personality, or quality of engagement. For me, this plot extended the debate by associating "expressivity with pandering, narcissism, voyeurism, and exhibitionism" (Rainer 2006, p. 243). She also explains that "[i]t was not until I had been through the Graham 'factory' and embarked on serious study with Cunningham that I could fully appreciate the heretical notion espoused by the Cage/Cunningham school-namely, the implicit humanity and emotionality of the human body" (ibid., p. 170).

2 See (Ramsay 1991). As Rainer notes in a 1976 interview, this is precisely what "unsettled" her about the group, and ultimately - along with the attention she received as a solo performer-caused her to leave: "It was a group that would not rehearse together. They would just go out there cold and wing it.... And I had a lot of ideas that required rehearsal, long rehearsal. ... The positions [of performers in Grand Union Dreams] didn't evoke anything in particular, but the combination, or the relationship, made for a dramatic situation. I was looking for minimal means for suggesting melodrama" (Rainer and Blumenthal 1984, republished in Rainer 1999, pp. 67-68).

3 See (Rainer 2006, pp. 409,464). Lives of Performers, 1972, Rainer's first "narrative" film, addresses the distinction between characters and performers; later films will work in the question of the narrator/author even more explicitly, just as the genres entailed by her film work- "documentary"; the feminist memoir-or essay-film, etc.-further complicates these distinctions.

4 Foster's seminal Choreography \& Narrative puts "narrative" into a different category than Heilbrun; in her hands, it stands for the incorporation of dance into "the body politic", as in: "By comparing dance with the corporealities instantiated in other practices, the ballet's choreographic conventions can be seen as particular stagings of the body's participation in the larger performance of the body politic" (Foster 1998).

5 It may be impossible to call Georges Balanchine's paroxysmal modernism "ended", but the advent of what has been called postmodern dance suggests as much. See especially (Crimp 2016, pp. 203-35). This essay is dedicated to Douglas's beautiful sensibility, his unwavering attention that dance especially rewarded, and his acute feminism. 
story. $^{6}$ ) Even if roles are, on one level, nothing more than the mode of transmission that allows a choreography to be taken up by more than one body (to exist as a score for performances, in the plural), on another, they also signify the way that we understand ourselves as abstractions, as vehicular: not "the character" or its context, but the empty thing we are at various points. In this perspective, dance's roles are parallel to the social roles that we assume, avoid, and create-those of student, neighbor, etc. It is not that we merely instrumentalize ourselves to become such things. The role is the means by which we project ourselves-our selves - into a temporality and spatiality that we cannot occupy constantly. It is the move of the self into spaces and times beyond the this here now; the move of the self into that which always remains, on some level, abstract to oneself. The nature of that move into that which is not here, particular to me, now, and its exchangeability (the fact that all of these roles exist because others enter and perform them too) is the way that dance does not merely mimic life, but tunes us to the modes of performance that populate our interior life or what could be called our selfhood.

This framework, including the rhetoric of the "self", might strike some readers as odd. However, dance provides us with a particular way to understand how we are cleaved, as social subjects, by the ways that productivity has not only monopolized the subject, but also insisted on leaving a remainder. Andrew Hewitt, glossing the German labor theorist Karl Bücher, describes how "vitalistic 'dance labor'" served as part of an affirmation of the subject divided by laboring/productive movement, and stipulates that "all movements whose purpose lies in the movement itself, however, are not work" (Bücher 1902, translated in Hewitt 2005, p. 44). ${ }^{7}$ On the one hand, what I am proposing here accentuates the ways in which dance in particular emphasizes the labor nature of the dance role: roles consolidate how professional, choreographed dance is work, by insisting on the transmitted and organized conventions of dance, and by extension, by including the dancer in social, economic, and aesthetic systems of reproduction. On the other hand, the role provides a kind of cover for the manners in which such reproductive conventionality, and the rigors of submitting to, inhabiting, and watching choreography, are themselves part of what selves seek-which is perhaps true of how we both fulfill and fight with the wider and inevitably reproductive realm of social roles. Choreographed dance uses the role to heighten the distinction between the generalized subject (even as it is tethered to and formed by concepts of race, gender, etc.) and the particularized self. The dance role does not stand in for that distinction but turns it into a source of pleasure and thought to be shared among dancers and, through performance, with audiences. ${ }^{8}$

\section{Rosas danst Rosas (1983)}

All the boys and the girls of my age

Walk down the street two by two.

All the boys and the girls of my age

Know what it is to be happy.

6 In her performances of the final "act" of Three Seascapes, the solo dancer "entered with an armload of white tulle and 'that coat', dropped both on the ground downstage right, and then proceeded to have a thrashing, screaming fit, flinging parts of the material into the air and rolling around in it ... [Dance critic Marcia] Marks wrote that it was as if "she awoke screaming from a nightmare." Archias further describes the related works-Three Satie Spoons (1961), Satie for Two (1962), and Three Seascapes - as presenting "these figures of the madwoman and the animal-child in a disturbingly unanchored way, without a narrative and with no identifiable boundary between the woman, the dancer, and her role.... Was her dance somehow autobiographical? Her viewer had nothing to attend to but Rainer's bodily drama, no other body through which she might, through identification, distance herself from the spastic other" (Archias 2016, pp. 50, 52).

7 Hewitt explains that for Bücher, "Dance was of interest because it promised—or threatened—a human laboring subject deprived of will. In other words, if thinkers and artists on the Left criticized alienated labor as unfree, anthropological research at the same time suggested that dance — which had been used to figure free, organic activity — was in fact, unfree because it involved no activity of will" (Hewitt 2005, p. 43).

8 See also Archias' discussion of the "general" and "general humans" as it applies to "the dancers in a classic Cunningham work", as well as Yvonne Rainer's Spiraling Down (2008) in (Archias 2016, p. 179). 
Eyes in eyes, hand in hand,

They go by, in love, with no fear of tomorrow.

Yes but I, I go alone, down the street, soul in pain,

Yes but I, I go alone, for no one loves me.

Françoise Hardy, "Tous les garçons et les filles de mon âge" (1964) ${ }^{9}$

Françoise Hardy's 1960s folk ballad, a chestnut of romantic feminine melancholy, would seem to have little to offer De Keersmaeker, whose choreography debuted in the 1980s with works that rigorously explore musical ideas and operations, a focus especially clear in her dances set to the music of Steve Reich. ${ }^{10}$ That is, De Keersmaeker can appear to be a stringent European formalist, not someone interested in sap, mass sentimentality, or even in the self that such sentimentality seems to invoke. In other words, far from Hardy's chestnut. Yet, De Keersmaeker's earliest dances are also striking for their performances of received notions of femininity: for example, the "Five Women-so lonely"11 of Elena's Aria (1984); the culotte-bearing flirts of her choreography to Bartók's Quatuor No. 4 (1986); or the grinningly victorious empress of Ottone Ottone (1988). In these early works, and especially in one of her earliest choreographies, Rosas danst Rosas (1983), she invites charges of rehearsing tired tropes of what femininity is or looks like. ${ }^{12}$ However, her interest in and use of clichés-or even merely stylized femininity-also provides a semi-concrete field of reference. These frameworks take her dancers from youthful anonymity into a field of cultural associations that remains usefully imprecise but is nonetheless markedly removed from the forms of dancerly abstraction developed in New York City in the 1960s and after that on European stages. ${ }^{13}$

That is, whereas Rainer's Three Satie Spoons (1962) might parody tropes of femininity-its forced smiles, its graceful extensions-Rosas danst Rosas, with its "pleasantly feministic" lineup, its "something revolutionary", took both feminism and femininity seriously, in equal and therefore confusing measure. ${ }^{14}$ De Keersmaeker's unique intervention in this early dance concerns her use of multiplicity to treat those clichés of femininity. She develops a kind of choreographic serialism-itself learned and transformed from the music of Reich and others-in which dancers either repeat exactly the same choreography or produce slight variations on a singular model that in turn produces different roles. In other words, her work evokes both the kind of singularity and its complementary plurality that Hardy describes as proofs of her selfhood. "Les yeux dans les yeux, la main dans la main": two by two go "the others", marching endlessly by. Except that in De Keersmaeker's earliest dances such

9 “Tous les garçons et les filles/De mon âge/se promènent dans la rue deux par deux/tous les garçons et les filles De mon âge/savent bien ce que c'est d'être heureux/et les yeux dans les yeux et la main dans la main/ils s'en vont amoureux sans peur du lendemain/oui mais moi, je vais seule par les rues, l'âme en peine/oui mais moi, je vais seule, car personne ne m'aime..." Translation my own.

10 Fase: four movements to the music of Steve Reich is De Keersmaeker's first dance to Reich's music; it was her second dance, immediately following the never-revived Asch, and succeeded her contact, "while studying in New Work ... some of Steve Reich's musicians: Shem Guibbory, Nurit Tilles, and Edmund Niemann" (De Keersmaeker and Cvejić 2012, p. 25).

11 This is the title of Rudi Laerman's response to Elena's Aria, in which he reminds himself "You once again enjoyed the preciousness of the gesture, the mixture of puerility and femininity." In (De Keersmaeker 2002, p. 74).

12 A particularly good text addressing this issue is (Keersmaekers 2017).

13 Along with the choreographers she encountered in New York City, De Keersmaeker's other key influences are Pina Bausch and William Forsythe (an American who became the Director of the Ballet Frankfurt in 1984). Forsythe and Bausch present European paradigms of abstraction, characterhood, and the role, especially as it relates to theatrical roles, to the sculptural, and to the spaces of the stage. These are all highly relevant issues that I do not wish to erase even if this is not the space for their unfolding.

14 These are the words of Cynthia Loemij, who took over one of Rosas danst Rosas' roles in 1992 and who has stayed with the company since: "I feel that Rosas danst Rosas belongs to the eighties. The aggression that emanated from it is no longer so prevalent: in the Netherlands, even the eighties were rather lukewarm. That production had something revolutionary, almost political, something pleasantly feministic as well: those four women who stood on the stage very timidly, yet without fear" (Van Kerkhoven 2002). My deepest gratitude for her always nuanced reflections to Cynthia, who I first met when I interviewed her and has become a treasured friend. 
as Fase and Rosas danst Rosas, the "two by two" are not heterosexual couples but duets of exclusively female performers. It is this contrast between an emphatically female them and a repeated $I$ that De Keersmaeker's je, as it were, originates. If Hardy is consumed with the narrative of the couple, De Keersmaeker anchors her notion of the singular in the plurality of the category "women".

Some of that plurality is described in the staging of Rosas danst Rosas, not only the array of four dancers, which will preoccupy most of my discussion, but the manner in which they are presented, as individuals and a group. They are dressed identically, in loose, open-buttoned and no-collared shirts over undershirts; loose skirts hitting just above the knee; socks worn with or without tights; and lace-up shoes of the no-name variety worn by nurses and other service workers (or, indeed, fashionable young women playing up what we now call "normcore" aesthetics). Their hair is worn loose, providing a key accessory in the dance: just as some movements will allow long hair to pool languidly or shake dramatically, a short crop allows the audience to see the dancer's gaze, whose direction is always highly intentional. The work's first cast-De Keersmaeker choreographed it on herself and the three other dancers who performed it in its first run: Adriana Borriello, Michèle Anne De Mey, and Fumio Ikeda-all wore their hair short (Figure 1). ${ }^{15}$ This violation of balletic convention underscored a notion of femininity both playful and functionalized, digging at the binaristic assumptions that supposedly underlie femininity while pointing - as her earlier work, Fase, had underscored-at the ways that seductiveness itself can emerge from the appearance of functionalism, labor, and even the identical multiple: that which is indistinguishable in itself. ${ }^{16}$

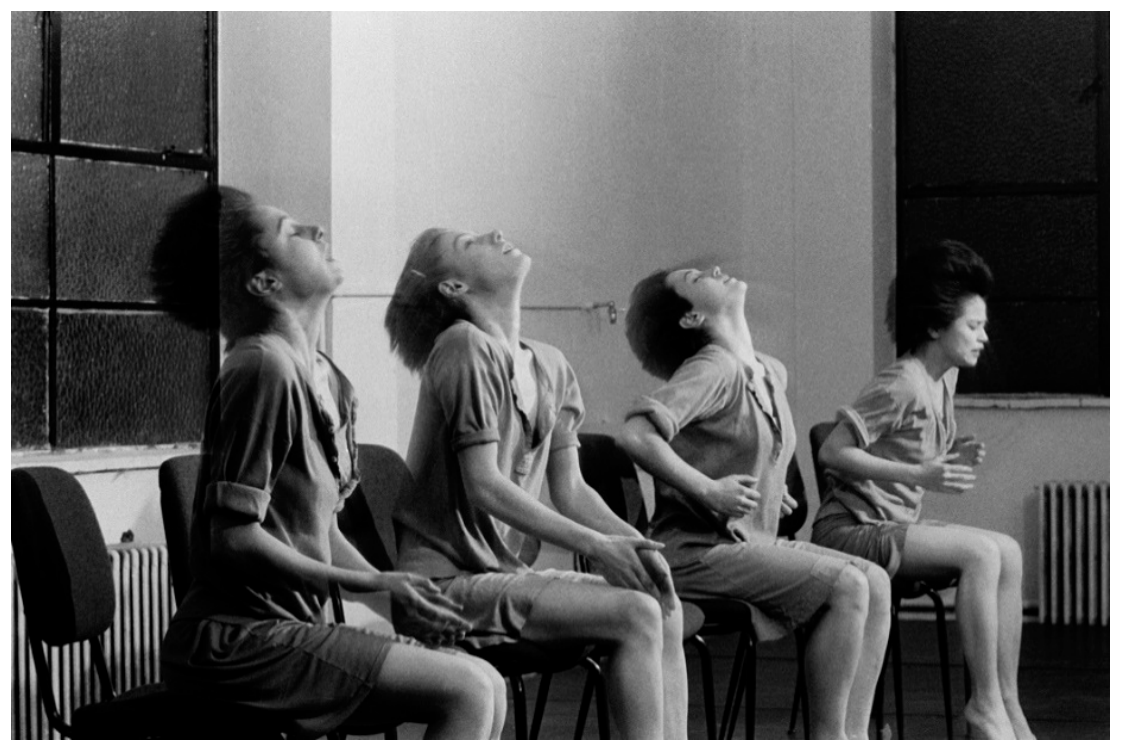

Figure 1. Rosas danst Rosas (1983) Anne Teresa De Keersmaeker/Rosas (C) Jean-Luc Tanghe. Used with permission.

15 Rosas danst Rosas premiered in May 1983 at the Théâtre de la Balsamine, Brussels, in the context of the Kaaittheater Festival. The work's dramatic lighting, designed by Remon Fromont, presages the choreographer's astute use of highly dramatic lighting in many works; the dancers designed their own costumes. See (De Keersmaeker and Cvejić 2012, p. 79).

16 Such fashionably short hair also poked at the binary between balletic rigor and whatever might be its opposite, whether in "modern" dance or indeed "popular" dance. The world of popular dance has in many ways "caught up" with Rosas, in a way that the extremely popular Re: Rosas:The fABULEUS Rosas Remix project has clarified. Just as many dances (the Renegade, the Orange Justice, to take two examples from 2018-2020) have spread online, De Keersmaeker (with collaborators, including Samantha van Wissen) has posted an online explanation of how to dance the second movement of Rosas (as well as explaining "the structure, the combination: how that dance was made"). Hundreds of videos of groups performing that movement have since been posted online. See https://www.youtube.com/watch?v=ZFtU0VnJoyk\&list=PLiH_xu1h5rNwan9zc3divV9lynbnzNM6 and https://www.rosasdanstrosas.be/en-home/. 
Rosas danst Rosas is best understood as an exploration of what it means to put four dancers, all women, on stage continuously for an hour and thirty-five minutes and have them essentially "dance out" questions of repetition, counterpoint, and what it is or means to dance in unison (Figures 2 and 3). In Rosas danst Rosas, each dancer depends on others but eventually fills out her role in a manner that subtly signifies "her" alone. That is, extended periods of synchronization and counterpoint (especially in the first two movements) mean that each dancer is formally bound to the three other dancers; in the third movement, each dances a solo that unfolds "her" style or role as different from the others. Then, over the years, new dancers taking on these roles might be assigned to them according to particularities of their bodies or "styles" of movement, thus generating resemblances and differences from the work as it appeared on that now-historical first cast. Thus, the unified foursome evokes not only the dance's "origin story" as a work choreographed among friends, but a question of how a singular self relates to a multiplicity of selves. ${ }^{17}$ That that multiple can be spread over time-over generations to come-is part of how the role functions in dance to explore the condition of multiplicity as it matters to contemporary selfhood. ${ }^{18}$

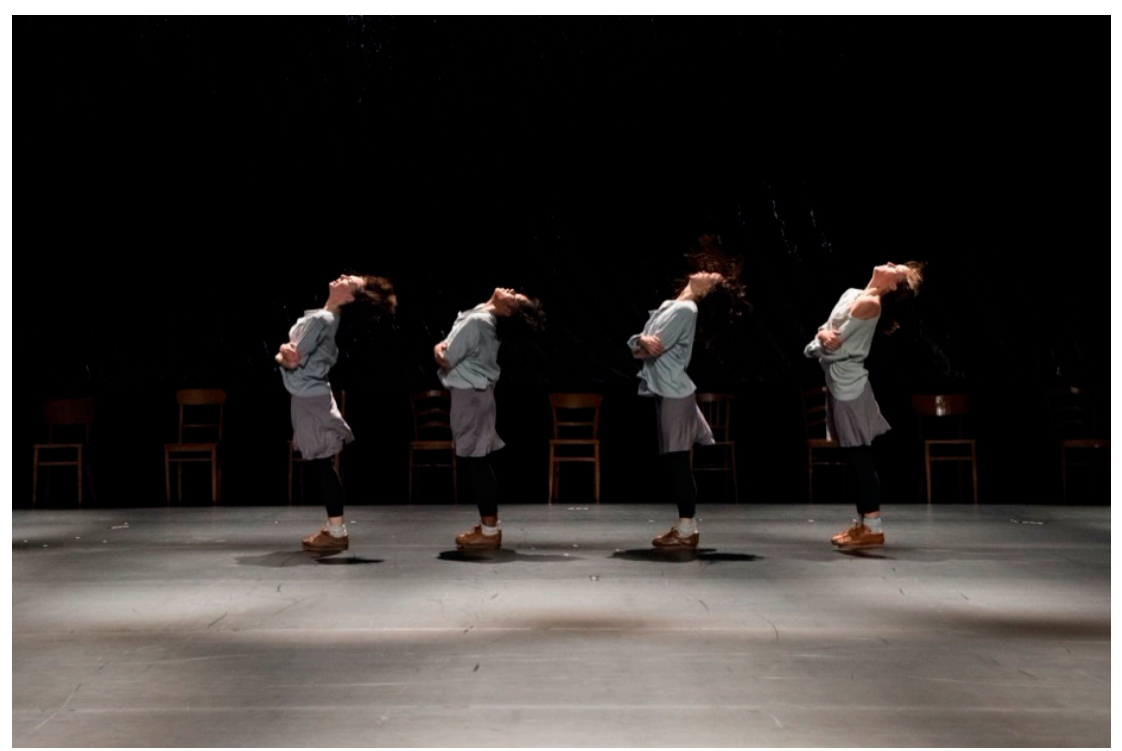

Figure 2. Rosas danst Rosas (2017) Anne Teresa De Keersmaeker/Rosas (C) Anne van Aerschot. Used with permission.

De Keersmaeker adopted the title of this work to name her dance troupe, Rosas, which she founded in concert with making and presenting Rosas danst Rosas. In that way, she permanently linked her professional identity to not only the initial foursome on whom this particular dance was based, but also to successive generations of professional dancers with whom she has worked since and who now form the basis of an even larger organization comprising a school, summer residencies, and more. ${ }^{19}$ The term "Rosas" is surprisingly complex: the singular, rosa, is a Latin term that names both a

17 De Keersmaeker at times refers to the making of Rosas danst Rosas as a collaboration: "It was created with and danced by four dancers who studied in the same period at Mudra [the school of dance that Maurice Béjart directed in Brussels, where De Keersmaeker did the majority of her dance studies], which is where they met each other ... " (De Keersmaeker and Cvejić 2012, p. 79).

18 I explore this question at greater length in my book-in-progress, Each One Other: Shape, Character, and Role in Contemporary Art.

19 The troupe has remained continuously operational since 1983, and "Rosas" has become a kind of umbrella entity, encompassing several educational programs—the international professional training studio called P.A.R.T.S. and "Dancing Kids", as well as "Bal Moderne", evenings in which a single, original, short choreography is taught to amateur dancers-as well as a filmography and repertory. Despite her flourishing "solo" career as a choreographer and dancer, the impulse to collectivism that makes Rosas such a powerful force in the Brussels and European art and performance scenes is important. 
plant genus and a spectrum of color. In the work's title, it is capitalized and thus indelibly evokes the Germano-Polish-Jewish female paragon of early 20th-century anarchist revolution Rosa Luxemburg. (Luxemburg nicely models the transnational nature of De Keersmaeker's hometown of Brussels as well as that of dance troupes generally.) Yet, it is not rosa or Rosa that titles the work or the troupe, but the plural Rosas. Indeed, that plural form articulates quite clearly the fold I am ascribing to the role: that which cleaves the performing self and that self that is generated onstage, separating and joining them and in so doing, pointing to their separateness as well as to the principle of separateness and togetherness that the dancers articulate as four dancers performing together, in precise synchronicity, onstage. Finally, Rosas danst Rosas means "Rosas dances Rosas": even if the noun is plural, the verb is conjugated in the third-person singular, identifying the plural noun as a whole, a singular entity. The title phrase builds the plural mode into the substantive Rosas, but that proliferation happens on either end of the singularized verb "dances." Rosas danst Rosas can thus be understood as promising a dance of the proper name and its claims to singularity and immediately withdrawing that promise. ${ }^{20}$ Or, it can show us how the singularity of the proper name depends on an action (dancing) that provides its encounter with itself-but only in the plural. That kind of complex, interdependent relationship of plurality to singularity is the hallmark of what De Keersmaeker allows to unfold among her performers not only in this dance but throughout her choreography.

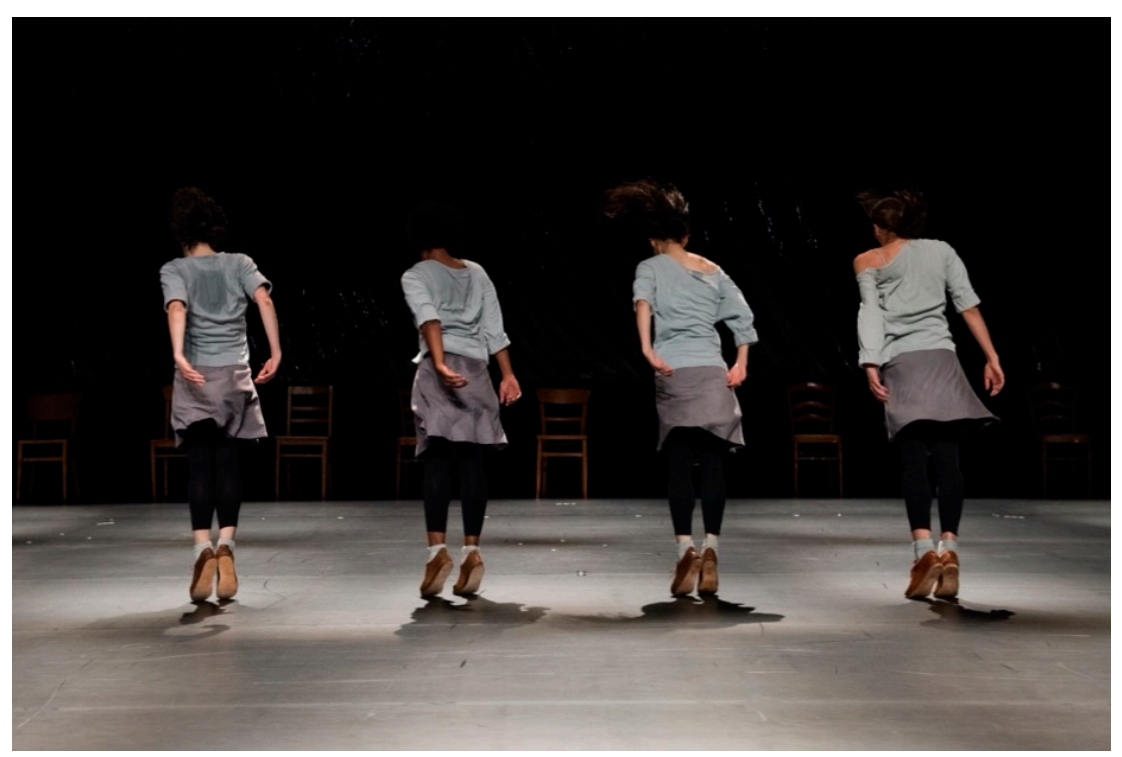

Figure 3. Rosas danst Rosas (2017) Anne Teresa De Keersmaeker/Rosas (C) Anne van Aerschot. Used with permission.

\section{Dancing Together}

A performance of Rosas begins with a "bang": a forceful, emphatically over-loud musical prolegomena immediately followed by a completely silent first movement. The music, composed by De Keersmaeker's friend and "music dealer", Thierry De Mey, sounds half minimalist-serialist, half industrial rock. ${ }^{21}$ We first hear it in semi-darkness; in De Keersmaeker's words, the music "is brutally mechanical, and grows to an almost dangerous high volume. The four dancers come onstage, stand,

20 Let us not forget the use of a Flemish/Dutch verb that means the same thing as its German, English, and French cognates; a verb as European as the troupe would eventually become international.

21 De Mey also made a remarkable film of the dance, as well as a number of other scores for and films of De Keersmaeker's work. De Keersmaeker explains that De Mey's composition-his first-was also heavily influenced by Louis Andriessen, the Dutch composer and teacher, whose amplified musical group Hoketus was unusual in its makeup (two of every instrument/instrumentalist: piano; electric piano, panpipe/panflute, saxophone, electric bass, percussionist) and its approach to collectivity, both of which were prescribed by Andriessen's 1976 composition of the same name, which he 
and fall straight onto their backs, going from verticality to horizontality." 22 None of the four dancers leaves the stage for the work's duration, and throughout, they perform in extraordinarily precise, sometimes contrapuntally ordered synchronicity. However, the first movement of their performance, after their collective fall, is conducted exclusively on the floor, lying down. As they begin an extended sequence of repeated movements-they lift their heads while lying on their stomachs; they roll over onto their backs; they draw their hands dramatically to their forehead; they writhe; they rest a moment, pensively, head on fist - the audience is invited to speculate: how do they synchronize so perfectly with one another, in silence (Figure 4)? If this is, in some sense, the spectacle of Rosas danst Rosas, it frames not only technical questions, but structural ones: how do four roles that merely reorder and eventually slightly adjust the same movements make a dance?

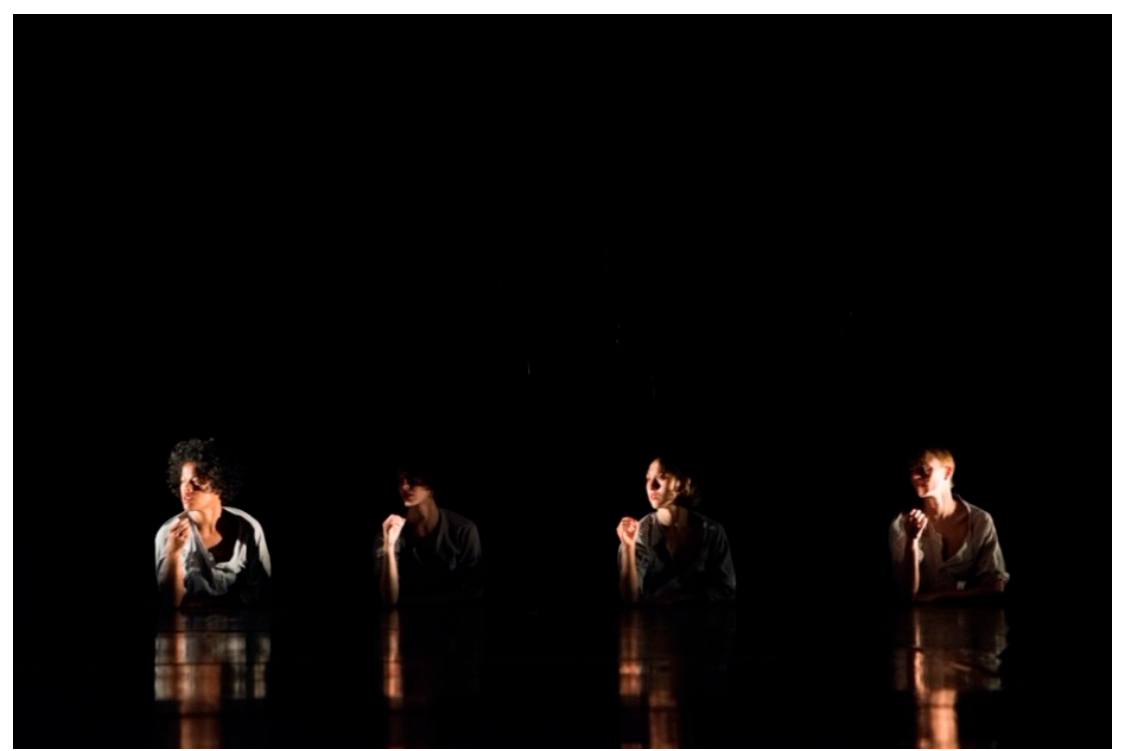

Figure 4. Rosas danst Rosas (2017) Anne Teresa De Keersmaeker/Rosas (C) Anne van Aerschot. Used with permission.

The first half of that question is easily answered: it is in part through their audible sighs and exhalations, the sound of one another's shirts brushing the stage or creasing against each body, that the dancers, moving in this first act without music, synchronize with one another. However, in Rosas the question of timing and synchronicity is also played against the question of "individuality" that seems to be portrayed through the particular movements that make up the dance. From the first moment, these dancers are showing us something about "the everyday". Part of this first movement is an intense, fast routine of audible exhalations and a gamut of movements ranging from the banal (a hand run through the hair, sitting up on two forearms) to the dramatic (a fist brought fast into the stomach, as if the dancer were stabbing herself). As they quickly roll, turn over, writhe, and cringe - at one point placing one hand on their foreheads and turning their heads, in the classic gesture of feminine despair-they are performing not only ordinary movements but ordinary gestures. Unlike the "ordinary movements" that composed so much of Judson Dance Theater's new range of motion in the 1960s, these gestures signal affect and, moreover, even signaling work itself, taken not as parody but as invitation. ${ }^{23}$ The dancers perform the quotidian insofar as it can be condensed but also expanded to

claimed would "make use of certain stylistic devices of minimal art [but] would at the same time criticise this style." See: http://www.boosey.com/cr/music/Louis-Andriessen-Hoketus/1542, accessed on 27 March 2020.

22 Interview in (De Keersmaeker and Cvejić 2012, p. 82).

23 That is, whereas a hand clenching hair in Rosas suggests a range of affects (panic, concern, flirtation, e.g.), it mostly opens the door to seeing the performance as full of affect, whereas the index fingers stretching, grinning open in Three Satie Spoons, works parodically, citationally. 
include affective life, at least insofar as affect can be raised to form or even exacerbated as indices of theatricality itself.

That is not all that the movements are, however. Indeed, the dance's forms-the shapes and rhythms that the bodies make, the sequencing of their movements, and most of all their repetition, acceleration and deceleration, and synchronization/permutation across the four bodies-are just as important. Across a multiplication "times four" of dancers doing exactly the same gestures in unison, we see a spectacle of synchronization and repetition and slowness or quickness. We also see the moodiness of a morning, a rousing from sleep, a cringeworthy thing remembered or action regretted (from the night before?). Performed first in rapid, electric bursts and then in decelerated, phrase-less slow motion, these movements are both "formal" and highly, maybe even innately theatrical. They speak not only to the conceit of Rosas danst Rosas - that it is a dance about a day in the life of a young woman-but also to the idea of showing that conceit spread across four women de-individuated in their synchronicity, even as the dance invests our attention in the notion of the individual, the one having a day. Thus, the first movement, in silence, evokes a fitful waking; the second movement, performed sitting on folding chairs to De Mey's highly percussive music, displays the mechanicity and congeniality of the workday (Figure 5). The third movement, which unfolds each dancer's singularity, her individual "style", is a sequence of four solos that, in De Keersmaeker's own terms, evokes the languid relaxation of late afternoon (Figure 6). ${ }^{24}$ In the fourth and final movement, we witness the "excess" of night, the kind of energy one might find in a nightclub (Figure 7). ${ }^{25}$ In the end, dance becomes expenditure, and the apparent differences between the dancers' styles recede again.

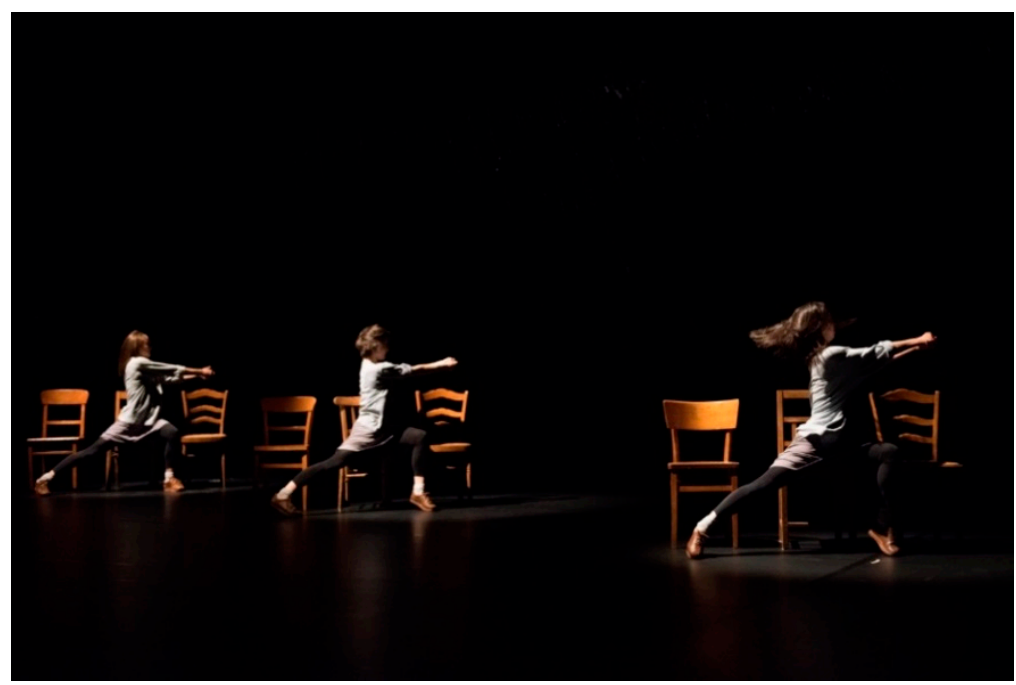

Figure 5. Rosas danst Rosas (2017) Anne Teresa De Keersmaeker/Rosas (C) Anne van Aerschot. Used with permission.

24 De Keersmaeker herself mentions Hardy's song in relation to the third movement “ . . . afternoon—we had always referred to it as 'aller à la plage' (going to the beach). It had a slight melodramatic touch à la Françoise Hardy's 'Tous les garçons et les filles de mon age'" ("Rosas danst Rosas," in De Keersmaeker and Cvejić 2012, p. 81).

25 Interview in (ibid., p. 81). The published interview is a transcription of the videotaped interview, which can be seen on the DVDs included in the boxed set of A Choreographer's Score. 


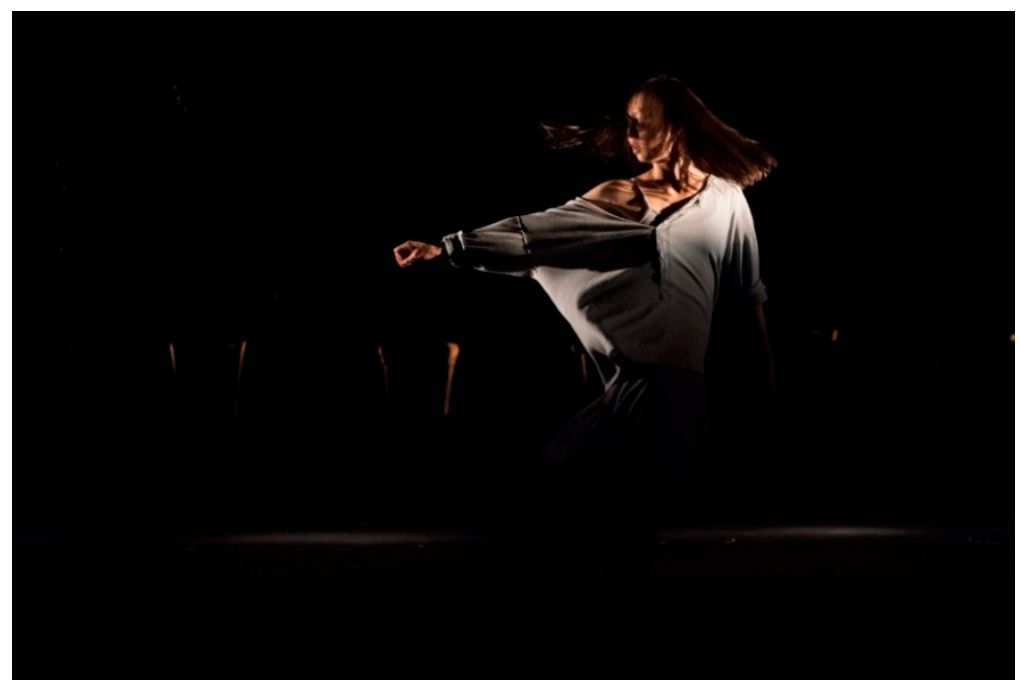

Figure 6. Rosas danst Rosas (2017) Anne Teresa De Keersmaeker/Rosas (C) Anne van Aerschot. Used with permission.

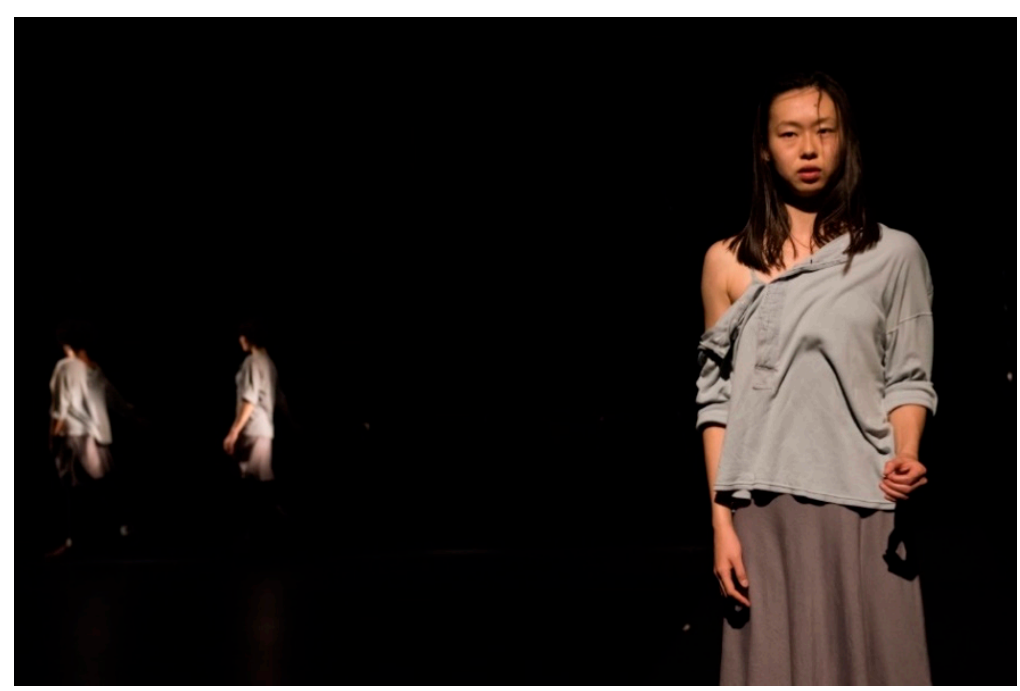

Figure 7. Rosas danst Rosas (2017) Anne Teresa De Keersmaeker/Rosas (C) Anne van Aerschot. Used with permission.

This notion of a dance that spans a day is both a quasi-narrative conceit that sets up the dancers as if they were "individuals" and works on a formal level to alter the terms of Rosas danst Rosas' conceit of permutation and variation (or phase-shifting). The four acts' movements loosen up and gradually expand across the stage, from the initial position of lying down, to sitting up in stationary chairs, to dancing across the stage. As the successive acts move the dancers towards a state of exhaustion, it also yokes them to the notion of a thing happening across all four dancers. This is different from the framework of dance as permutable and repetitive motion without a human toll. Repetition and permutation are both taking place and also relating to another question, and that "other question" is related to the innately human. "Mes jours comme mes nuits sont en tout points pareils": My days like my nights are exactly the same. Unlike others who live outside the regime of pure repetition at the base of this core loneliness (others, that is, who are not "me"), I am alone. Repetition draws the "me" into being and Rosas' dancers into a mode of being together: both at once. 


\section{Solos}

It is the third movement of Rosas that features solos and forces the question of dancerly "style" into counterpoint with this formalist "me" - the same across three dancers, which we watch in the first two movements. ${ }^{26}$ Each dancer had a slightly different style, and the differences in their style were highlighted in the sequenced solos of the third movement, performed against the "basso continuo" dance in unison sustained by the other three dancers. As De Keersmaeker's astute interlocutor, dramaturg, and in-house musicologist Bojana Cvejić describes:

The structure is based on the division between three dancers performing the same phrase in unison in the background-what we call "basso continuo"-while another dancer continuously steps out as a figure in either a 'danced' or a 'theatrical' solo. The individuality of the dancers is featured through contrasting qualities that alternate between them; the first was a 'danced' solo by Anne Teresa, known for her preference for the 'attacked' character; then came Fumiyo's 'theatrical' solo, based on daily gestures in a staccato manner; the third is Adriana's 'danced' solo in a lyrical, legato, and suspended character; and the fourth is a 'theatrical' solo by Michèle Anne, which had the lyrical, melodramatic tone of seduction.

(De Keersmaeker and Cvejić 2012, p. 98)

The manner in which each dancer performed (when not adhering to De Keersmaeker's demand for a perfectly synchronized and calibrated energy expenditure) is drawn out in her solo. Ikeda dances with a strong, punctuating sense of "attack", or what the choreographer calls "tjak... designating an abrupt, attacked, sometimes nervous, other times violent quality of movement that De Keersmaeker had an affinity for in her own dancing" (Cvejić 2012). De Mey and Borriello perform more languidly, and De Mey's solo in particular features a legato swaying of the hips. Individual style, in other words, becomes motif, and motif becomes the basis of each dancer's solo. Each performer becomes more uniquely "herself" against that "basso continuo", or baseline, performed by the group (Figure 8). ${ }^{27}$

Each dancer also becomes an embodiment of a different variant of "femininity", the term that proved a catchword in the work's initial reception. ${ }^{28}$ As Cjević explains, the notion of femininity arises from the "expressivity [that] is inextricable from the construction of movements in the early works, ... [that] morphologically and syntactically shapes the movements and their flow" (ibid., p. 14). Femininity is expressive and morphological? Possibly. However, the interesting aspect of Rosas danst Rosas seems to lie precisely in the way in which that "expressivity" is countered with a structure that itself mitigates the notion of something like a femininity that can be exteriorized or that exists as form. Femininity is not only a shared condition in Rosas, but one that arises through the structure of repetition and variation, the generic played against-eventually, in the third movement-the specific. Like the "gamut of tones" that Cjević isolates, from the De Keersmaekean attack to De Mey's sultry melodrama, the question of proprietorship — who owns a kind of femininity—is only possible within a notion that the gamut is shared.

Here, we move away from the question of whether something like femininity is "constructed" or not and into the manner in which dance allows it to become both hyperbolized within the singular

26 As De Keersmaeker notes, Rosas, "like many others afterwards, bears the personal expression of the particular dancers I made it with, of their bodies and movements, which to a certain extent shape the vocabulary and energy of the piece" (De Keersmaeker and Cvejić 2012, p. 115).

27 As in so many of her dances, a musical structure is used as a figure to help determine staging or another mode of spatial organization. Basso continuo, a harmonized bass line, describes the quieter, thrumming look of the three dancers executing the standardized version of the movements behind the soloist. The basso continuo, in other words, operates like the harmonics played by the three other members of the jazz quartet as the soloist takes his turn. It amplifies the solo and couches it, framing it with a sense of the collective against which it distinguishes itself.

28 "The overarching characteristic of this period is a sense of femininity pervading through all movements, explicitly manifesting itself in the gestures of running the hand through the hair, uncovering shoulders, showing the behind-the list of Rosas trademarks. Admittedly, the expression of femininity was a contentious issue ... " (ibid.). 
dancer as a function of personal style and also circulated across the temporally extended group of dancers who will perform each role over decades (Figures 9 and 10). Whereas a dancer today might perform De Mey's or Ikeda's role, they are not interchangeable. Each has not only her own position on stage at any given time but her own solo in the third movement; a dancer might be cast into a performance of Rosas danst Rosas (Figure 11) according to body type, style of movement, and sometimes even physical resemblance to the original model for each role-or none of the above. Like the concept of tjak itself, the role couples the performer as a self with the movements onstage. ${ }^{29}$

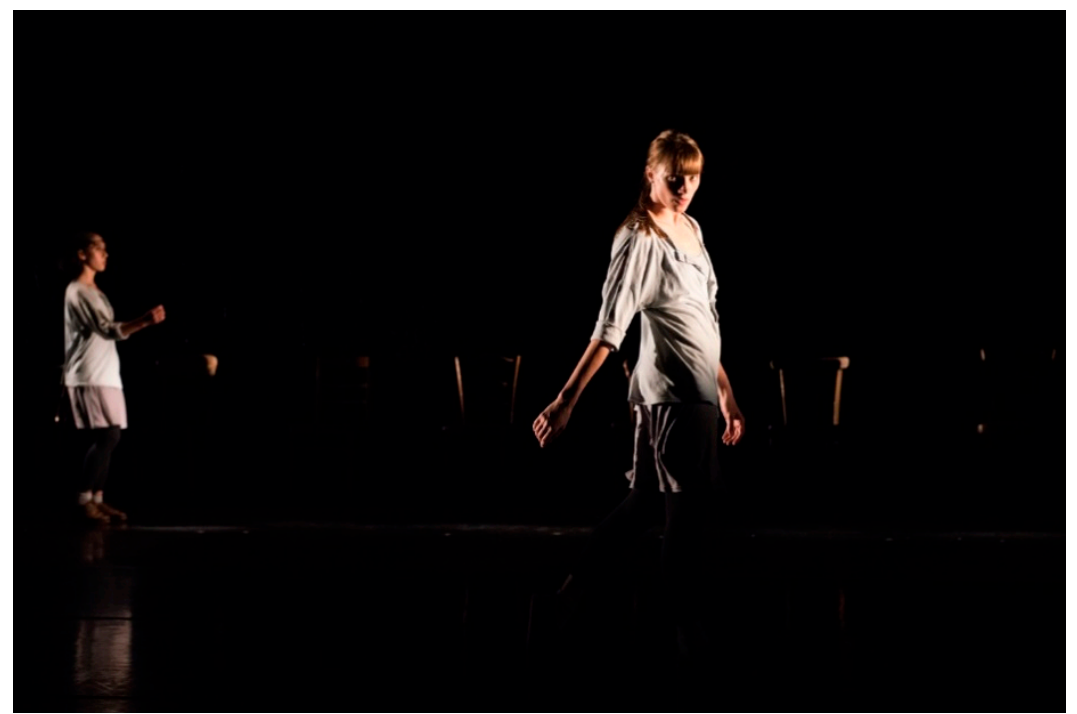

Figure 8. Rosas danst Rosas (2017) Anne Teresa De Keersmaeker/Rosas (C) Anne van Aerschot. Used with permission.

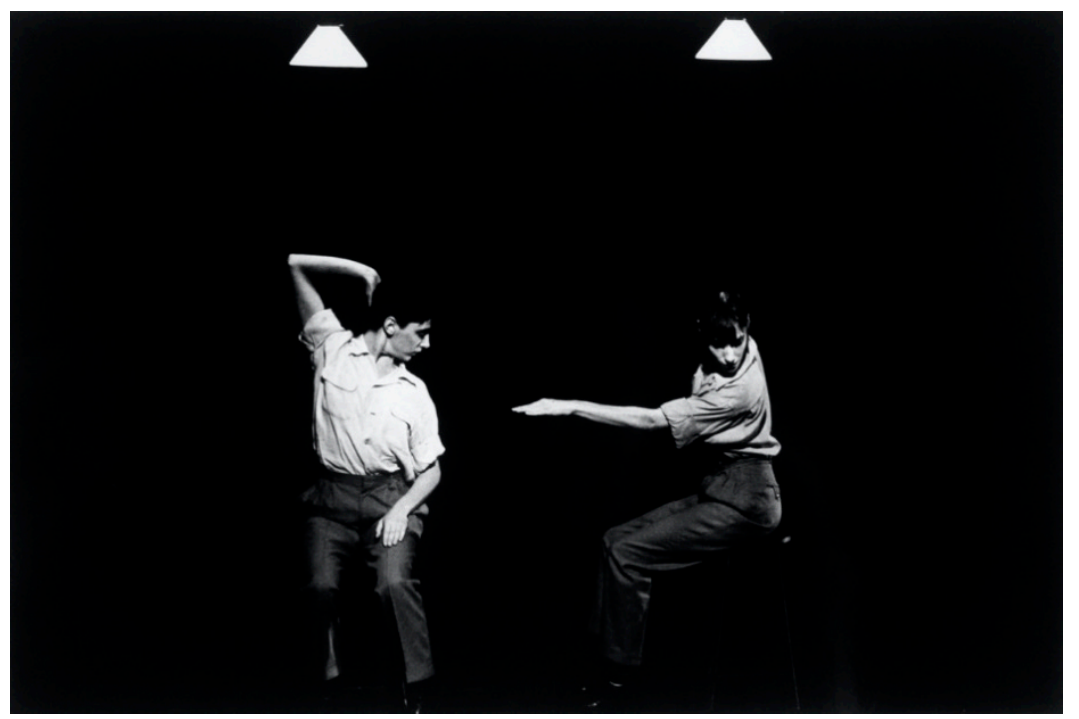

Figure 9. Fase (1982) Anne Teresa De Keersmaeker/Rosas (C) Herman Sorgeloos. Used with permission.

29 In this, it builds on the origins of ballet as described by Susan Foster, discussing the Baroque dancer Louis Dupré: dance itself could "gesture a manner of physical being ... [it] vectored significance away from specific messages and toward a manner of messaging. Each ballet interlude danced out states of feeling but also referenced the body's expressiveness, and this provided a source of power and identity for dance within the opera-ballets" (ibid., p. 29). 


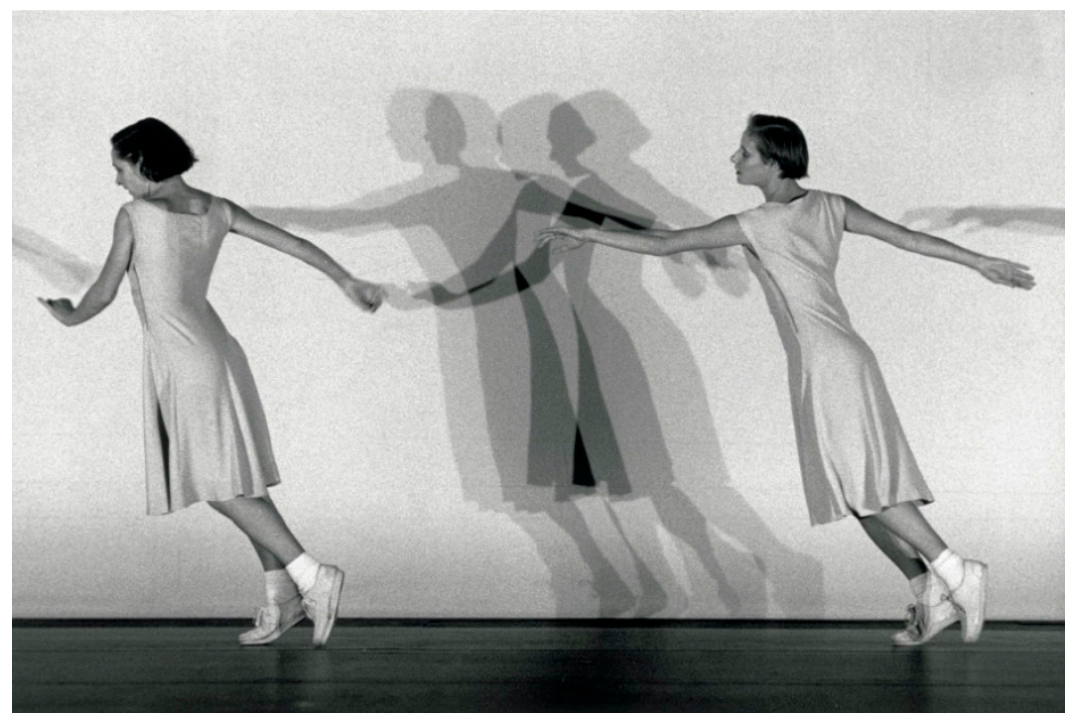

Figure 10. Fase (1982) Anne Teresa De Keersmaeker/Rosas (C) Herman Sorgeloos. Used with permission.

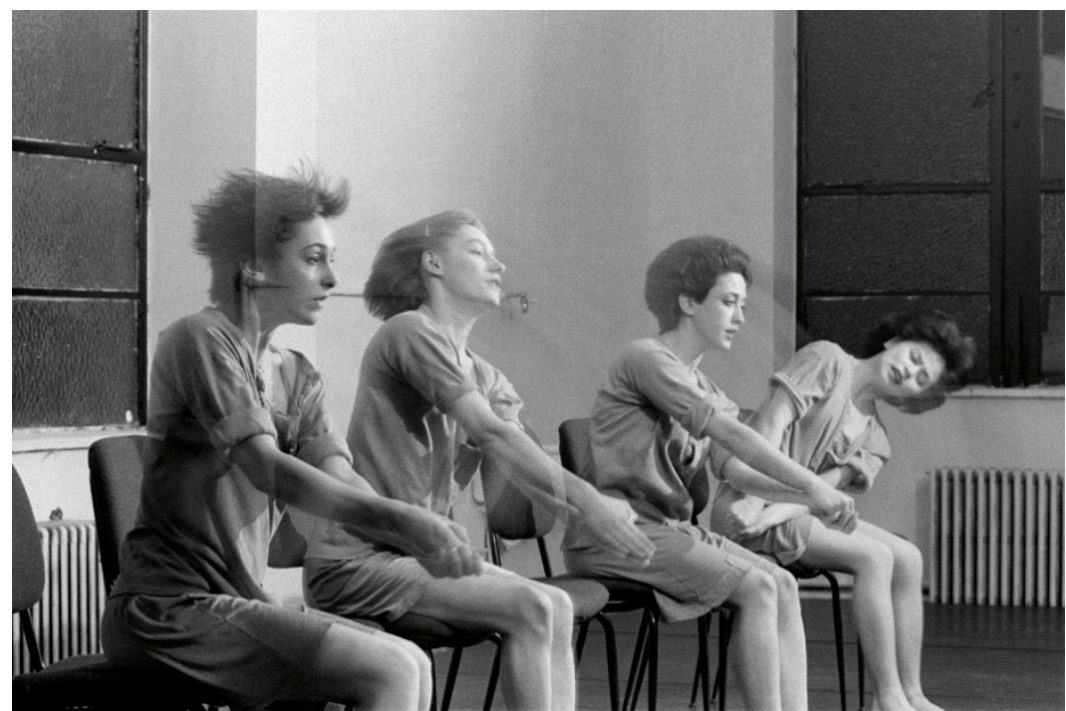

Figure 11. Rosas danst Rosas (1983) Anne Teresa De Keersmaeker/Rosas (C) Jean-Luc Tanghe. Used with permission.

Even if we often do not consider dancers as offstage personas, one aspect of the role is how it concretizes our sense of performers as different from one another. This difference does not reduce to any kind of characterological distinction: the four dancers in Rosas danst Rosas stop short of becoming four different characters, or four portraitists describing how young women generally (or, possibly, dancers specifically) wake up and get through the day. ${ }^{30}$ Instead, they are variations on a theme, with a caveat: the theme is themselves and/or the capacious notion of a day in the life of a young woman. The and/or is underscored in Rosas danst Rosas, just as the ambiguity of the singular/plural in its title is its title. In this thematic reading, conventionality itself comes to authorize the work: not only the conventions of femininity, but also the conventions enabled by an of femininity, a belonging together

30 This is a distinct possibility that Rosas opens up: that what De Keersmaeker is showing us is precisely "a day in the life" of not just women in general but young dancers such as herself and her peers on whom she based the choreography of the piece. 
of all four women inside one choreography that is both unifying and subtly differentiating. It is the structure of generality and individuality that is at stake.

Lauren Berlant, discussing the relation of individuals living in the world to conventions or "banal iconic things" that enable individuals to not only live but "love" conventionality, writes:

the convention is not only a mere placeholder for what could be richer in an underdeveloped social imaginary, but it is also sometimes a profound placeholder that provides an affective confirmation of the idea of a shared confirming imaginary in advance of inhabiting a material world in which that feeling can actually be lived. In short, this affair is not an assignation with inauthenticity.

(Berlant 1988)

The role is an expression both of conventionality and of shared attachments to it; in Rosas danst Rosas, it could be defined both as femininity and as a framework that is itself "pure"-a framework of transmission and exchange that excludes the idea that conventions exist outside of us. In its insistence on a notion of girlhood or young womanhood as a category for its performers and as a theme, it reaffirms that its storylessness has a gender and moreover that, in that gendering, "this affair is not an assignation with inauthenticity". It does so even as it insists-digging in as repetition, as theme and variations-on the formalism and rigor of its abstraction. To have modeled solos on the performers "themselves", allowing an idea of each young woman/dancer to surface, is to have provided the "authenticity" that is itself lodged in convention (the repetition, the basso continuo). The work derives simultaneously from the abstraction of its movements and the multiplicity that arrives thanks to the essentially fugal nature of Reichian "phase-shifting".

\section{Out of Step}

The work De Keersmaeker completed just prior to Rosas danst Rosas was Fase, Four Movements to the Music of Steve Reich (1982), consisting of a solo and three duets. Fase adopts Steve Reich's system of using "phase-shifting", in which instruments (violin or piano) or clapping hands or a piece of recorded speech play "against" something like the "basso continuo" that De Keersmaeker describes. In a "live phase" composition such as Piano Phase (1967), two pianists begin by playing an identical rhythmic/melodic pattern in unison; while one performer continues to play unvaryingly, the "second pianist increases his tempo very slightly ... until he is finally one sixteenth note ahead of the unchanged figure of the first pianist. The phasing process pauses at this point, as the newly shifted rhythmic configuration is repeated several times" (Schwartz 1980, p. 386). In the case of Reich's Violin Phase (1967), the score for De Keersmaeker's "solo" in Fase, a "live violinist plays against one, two, and finally three pre-recorded tapes of himself" (ibid., p. 387). ${ }^{31}$ The music and cultural critic K. Robert Schwartz continues:

The same twelve-beat rhythmic/melodic figure is recorded on all three tape channels, but in different phase positions (i.e., the same pattern but with three different downbeats): Track One is four beats behind Track Two, while Track Two is eight beats behind Track Three. Besides the different stationary phase positions of the tape, the performer himself carries out a live phasing process by playing the same figure as that of the tapes, but moving slowly ahead of the various channels.

31 Actually, it is possible for multiple violinists to play Violin Phase-omitting the use of a tape recorder-and more recently, different technologies have replaced the reel-to-reel tape recorder and other instruments of sound recording and amplification ("microphone, loudspeakers, amplifier, mixing board, and assistant") that Reich not only prescribes in his "Directions for Performance" published with the score in 1979, but also arranges spatially in a diagram included with the score. See (Auner 2017). 
Most significant in Violin Phase is Reich's conscious employment of the unexpected resulting patterns. These figures, unforeseen polyrhythmic, melodic, and harmonic combinations that occur as a result of identical material being phased against itself, are constantly in a state of flux.

(Schwartz 1980, p. 387)

Phase-shifting is thus a manner of understanding not only rhythm but also its relation to melody. It dislodges the assumption that melody is primarily something carried for example by an instrument or voice (or many instruments or voices playing in unison) and makes it something that can emerge both in auditory experience and from processes of repetition and overlay, a kind of temporal equivalent to the seriality and negative spaces so critical to artistic Minimalism (lending the term "minimalist" to early works by Reich, Philip Glass, John Adams, and others). In Reich's work, this emergent melody hinged crucially on the role of technology-particularly in works such as It's Gonna Rain (1965) and Come Out (1966), the latter of which provides the score for the second movement of Fase.

In the second duet of Fase, in which two performers perform while sitting on chairs, De Keersmaeker underscores an aspect of mechanicity that is indelibly associated to labor. The dancers' identical costumes-loose, pleated pants and button-down shirts with the sleeves rolled up, as well as their repetitive movements and attentive stares-evoke particular forms of mechanized labor such as switchboard and train operators (Figure 9). In the 21st century, performances of Fase can seem to reference almost obsolete forms and ideals of labor, just as Reich's original use of reel-to-reel tape recorders is today not only difficult to reenact but also itself a marker of the work's historical moment. However, it is not only the out-of-time quality that Fase's image of labor signals: labor provides the very condition of multiplicity that is invoked here and in De Keersmaeker's next dance, Rosas danst Rosas.

What we see unfolding across the ninety-five minutes that make up a performance of Rosas danst Rosas is precisely what is implied in its title: a status for the self dancing, in which the dancer pluralizes ("rosas") while remaining self-identical ("Rosas"). Self-identical in this instance means a relation to the proper name-that denoted by the capitalized R. "Pluralizes", despite its echo with "pluralism", means merely to make plural. One body cannot multiply - though it sort of does in Fase, when two dancers, side by side, are spot-lit so that, at times, their two bodies become four or more figures (according to the shadows on the screen behind them) (Figure 10). One body does not simply become an image of its own multiplicatory potential, but one self can become-or be seen-as if it were one whose basic form is to be many. Not many in itself-not an instance of self-destabilizing multiplicity, as we have come to understand the subject, cleaved from within, multiple in itself-but one of many. Rosas danst Rosas' dancers are dislodged from the self-identical in the same manner that a "melody" is dislodged as the product of repetition and overlay in Violin Phase. They are not merely inside a plurality comprised of different selves, nor are they each only one. They dance a conception of selfhood that is itself loosened from the regular distinctions between individuality, multiplicity, and collectivity; these are selves that refer in their constitution as selves to the status of the multiple.

\section{Multiples and Feminism}

At times, in Rosas, multiplicity is complicated by the insertion of something like a dancer's personal style-this one's legato, that one's tjak-making the conventional notion of the role increasingly resemble character. However, here, I wish to set the multiple into relation to two crucial turning points in the progression of feminist thought. The first belongs to Luce Irigaray, one of Cvejic's sources: an apt thinker to plumb as the Belgian feminist is only one generation older than De Keersmaeker, and her Ce Sexe qui n'en est pas un was published in 1977, less than five years before De Keersmaeker made Rosas danst Rosas. Irigaray bases her feminism in a conception of femininity that is in turn anchored in the (female) subject as a subject of language: to "play with mimesis is thus, for a woman, to try to recover the place of her exploitation by discourse", to "make visible, by an effect of playful repetition, what was supposed to remain invisible: the cover-up of a possible operation of the feminine in language" 
(Irigaray 1985, p. 76, cited in Cvejić 2012). Neither language nor discourse are irrelevant to dance, sometimes presupposed (falsely) as a mute art: more obviously, the dancer's body, like any other, is produced by discourse as much as biology. ${ }^{32}$ More to the point here: what situates Irigaray's conception of femininity within her own feminism is a notion of the "effect of playful repetition" that would enable the deconcealment of how "the feminine" itself-apparently on such full display in Rosas - operates as signification. In other words, Irigaray's theory relies on a conception of femininity in order to understand and operate a conception of inhabitation itself as a critical logic. The former is in some ways the progenitor of the latter; "the feminine" is a necessary condition for understanding "the critical" for Irigaray, because the kind of inhabitation that she considers critical is itself a mode of the feminine.

Such repetitions and inhabitations are part of the universally appropriative nature of the role, as in "One must assume the feminine role deliberately": one "assumes" by repeating, at least in fragments (Irigaray 1985, p. 76). ${ }^{33}$ The role in this way becomes itself feminist or at least shows us how the Irigarayan model might look as a formal model: the process of assuming and inhabiting is the model of critique itself. In showing the format of that assumption, how the role is structured by an all-female cast of dancers, however, Rosas frames the pleasure that the formalism of the role offers. Its rigor, emptiness, and, indeed, its storylessness are part of a proto-feminist deployment of the feminine, just as they are an argument for the pleasures of formalism itself. As Irigaray asserts, mimicry and role playing are not merely critical moves, but deeply linked to pleasure, play, and "nourishment". As Rosas shows us, there is intensity and desire inside the work of "assumption". To assume the rigor of a role is to play to a seduction that can itself be captivating. At the same time, the fever pitch that the dancers reach in the work's final movement is only one index of the pleasure that begins, for Rosas' audiences at least, with the effects of synchronization and differentiation, a vision of sameness and difference fanning out as a hypnotic pattern.

If this feels too close to the feminism of 1977/1983 - the period between Ce Sexe's publication and Rosa's debut - then the second moment belongs to our present. Let us remember that the role is different from character insofar as it is a mere vehicle, without the need to mimic or indeed perform the "interiority" of a self in the ways that characters demand. Can roles therefore become an ideal form for thinking about this distinction between having a self and basing that sense of selfhood in one's interiority? Our conceptions of how subjects are formed are based on ideas such as internalization (for example, of subject-producing norms, concepts, or values) or indeed externalization (manifesting the behaviors that concretize our standing as subjects). Roles, instead of playing along with such bifurcations, offer a way to get at our sense of being not only individual and among others, but like others, even progressing from a sense of likeness to a sense of self and the multiplicity of selves. In placing each role in such close proximity to others and allowing each dancer to occupy a role only minutely different from others-but lodging so much pleasure and significance in the scale of that minuteness-De Keersmaeker offers a modality distinctly other to that of the interior and the exterior, the subject and her structures.

Additionally, De Keersmaeker's play on appearances-especially her staging of the look of late-industrial workers, a look that is barely updated for more recent performances-imbricates the regimes of late capitalism inside her works' performances of performance. Berlant, in an article on what she calls "lateral agency", considers the possibility of a "practical sovereignty ... [announcing] unconscious and explicit desires not to be an inflated ego deploying and manifesting power" - in other

32 De Keersmaeker, especially in her early work, uses both language and voice. See such works as Elena's Aria (1984), Bartok/aantekeningen (1986), and Verkommenes Ufer/Medeamaterial/Landschaft mit Argonauten (1987), all of which receive brief texts in (De Keersmaeker 2002).

33 The critical power of Irigaray's prescription (of mimicry) is clarified in the next line: "Which means already to convert a form of subordination into an affirmation, and thus to begin to thwart it." Meanwhile, the French verb assumer suggests a conscious acceptance and affirmation of a state of being, similar to the English phrase "to assume responsibility". 
words, a sovereignty that is not about the self-as-one or indeed those traces of narrative drama that conventional ideas about emotionality and agency invite ("we persist in an attachment to a fantasy that in the truly lived life emotions are always heightened and expressed in modes of effective agency ... ") (Berlant 2007, p. 757). Berlant gestures instead at the temporalities and economies "of ongoingness, getting by, and living on, where the structural inequalities are dispersed, the pacing of their experience intermittent" (ibid., p. 759). For Berlant, "the body and a life are not only projects but also sites of episodic intermission from personality, of inhabiting agency differently"; here, I am proposing that the role is similarly not about agency as such, but about the ways in which "the body and a life" might signal the economies of circulation, interdependence, and exchange in which we find ourselves trading roles.

The role is a way to see in the multiple a place for the individual to sense the pleasurable formal work undertaken through repetition and difference. It is also a way to take pleasure in the absence of story, in the pure rigor of that which can be passed down-or better, across - from body to body, from person to person. If, in the social realm, the role can also entail forms of violence (insofar as being an employee or an unemployed person-or for that matter a son or a father-can be violent), the role is one of the key pleasures of dance. Seeing a body dance a role is not only the fulfillment of a balletomane's desire: it is seeing the shiftiness and ambiguity with which any body onstage takes its place that is itself pleasurable. The body inhabits that which does not belong to it alone. That condition, which I am calling storylessness, is not the same as what Balanchine or Pollitt meant by that term. It is a storylessness that in the best-case scenario reverses the anguish that can result from "erasing singularity from individuality to create the generic." Bodies are no longer merely "instance[s] of structure" but instances of selfhood that lie precisely in the exchange and circulation of common materials, and in exchangeability and circulation itself. This is not an escape route that will work in every situation, on every body: it is a privilege, but precisely that privilege that storylessness in dance opens up in our time.

Funding: This research received funding from the Fellowship Program of the American Council of Learned Societies.

Acknowledgments: Many thanks to Juliet Bellow and Elise Archias for their invitation and wonderfully generative feedback, as well as to the anonymous reviewers for Arts whose input was similarly treasured. Thank you also to Hans Galle for his help with the images illustrating this text, and to Anne Teresa de Keersmaeker for her generosity and her remarkable work.

Conflicts of Interest: The author declares no conflicts of interest.

\section{References}

Archias, Elise. 2016. The Concrete Body: Yvonne Rainer, Carolee Schneeman, Vito Acconci. New Haven and London: Yale University Press.

Auner, Joseph. 2017. Reich on Tape: The Performance of Violin Phase. Twentieth-Century Music 14: 77-92. [CrossRef]

Balanchine, George. 1992. Marginal Notes on the Dance. In The Dance Has Many Faces, 3rd ed. Edited by Walter Sorell. New York: Columbia University Press, p. 40. First published 1966.

Banes, Sally. 1998. Dancing Women: Female Bodies on Stage. New York and London: Routledge.

Berlant, Lauren. 1988. The Female Complaint. Social Text 19/20: 237-59. [CrossRef]

Berlant, Lauren. 2007. Slow Death (Sovereignty, Obesity, Lateral Agency). Critical Inquiry 33: 754-80. [CrossRef] Bücher, Karl. 1902. Arbeit und Rhythmus, 3rd ed. Leipzig: Taubnerp.

Crimp, Douglas. 2016. Agon. In Before Pictures. Brooklyn, Chicago and London: Dancing Foxes and University of Chicago.

Cvejić, Bojana. 2012. Introduction. In A Choreographer's Score: Fase, Rosas danst Rosas, Elena's Aria, Bartók. Brussels: Rosas, Mercatorfonds, p. 15.

De Keersmaeker, Anne Teresa. 2002. Rosas: If and Only If Wonder. Tournai and Brussels: La Renaissance du Livre/Rosas. 
De Keersmaeker, Anne Teresa, and Bojana Cvejić. 2012. A Choreographer's Score: Fase, Rosas danst Rosas, Elena's Aria, Bartók. Brussels: Rosas, Mercatorfonds.

Foster, Susan Leigh. 1998. Preface. In Choreography E Narrative: Ballet's Staging of Story and Desire. Bloomington: Indiana University Press, p. xvi.

Heilbrun, Carolyn G. 2008. Writing a Woman's Life. New York and London: W. W. Norton \& Company. First published 1988.

Hewitt, Andrew. 2005. Social Choreography: Ideology as Performance in Dance and Everyday Movement. Durham and London: Duke University Press.

Irigaray, Luce. 1985. This Sex Which Is Not One. Translated by Catherine Porter. Ithaca: Cornell University Press.

Keersmaekers, Floor. 2017. Womanhood in Rosas Danst Rosas. Available online: https://www.rosas.be/en/news/ 592-womanhood-in-irosas-danst-rosasi (accessed on 10 November 2019).

Kirstein, Lincoln. 1984. Four Centuries of Ballet: Fifty Masterworks. New York: Dover.

Pollitt, Katha. 2008. Foreword. In Writing a Woman's Life. Written by Carolyn G. Heilbrun. New York and London: W. W. Norton \& Company, p. xvi. First published 1988.

Rainer, Yvonne. 1974. A Quasi-Survey of Some 'Minimalist' Tendencies in the Quantitatively Minimal Dance Activity Midst the Plethora, or an Analysis of Trio A (1966). In Yvonne Rainer, Work 1961-73. Halifax: The Press of the Nova Scotia College of Art and Design, New York: New York University Press.

Rainer, Yvonne. 1999. A Woman Who ... Essays, Interviews, Scripts. Baltimore and London: Johns Hopkins University Press.

Rainer, Yvonne. 2006. Feelings Are Facts: A Life. Cambridge and London: MIT Press.

Rainer, Yvonne, and Lyn Blumenthal. 1984. Interview by Lyn Blumenthal. Profile 4.

Ramsay, Margaret Hupp. 1991. The Grand Union (1970-1976): An Improvisational Performance Group. New York: Peter Lang.

Schwartz, K. Robert. 1980. Steve Reich: Music as a Gradual Process: Part I. Perspectives of New Music 19: $373-92$. [CrossRef]

Van Kerkhoven, Marianne. 2002. Trying to Capture the Structure of Fire: 20 Years of Rosas. In Rosas: If and Only If Wonder. Tournai and Brussels: La Renaissance du Livre/Rosas, p. 37.

(C) 2020 by the author. Licensee MDPI, Basel, Switzerland. This article is an open access article distributed under the terms and conditions of the Creative Commons Attribution (CC BY) license (http://creativecommons.org/licenses/by/4.0/). 